\title{
Not All Dual Users of Cigarettes and E-vapor Products Are the Same: Biomarkers and Tobacco Use Behavior in Subpopulations of Dual Users From the PATH Wave 1 Data
}

Pavel N. Lizhnyak

Altria Client Services Inc

Richard B. Noggle

Altria Corporate Services Inc: Altria Client Services Inc

Lai Wei

Altria Client Services Inc

Jeffery Edmiston

Altria Client Services Inc

Elizabeth Becker

Altria Client Services Inc

Ryan A. Black

Altria Client Services Inc

Mohamadi Sarkar ( $\nabla$ mohamadi.sarkar@altria.com )

Altria Client Services Inc https://orcid.org/0000-0002-1167-6140

\section{Research}

Keywords: Dual Users, Cigarette Smokers, E-Vapor Users, Biomarkers of Exposure, Biomarkers of Potential Harm

Posted Date: September 28th, 2021

DOI: https://doi.org/10.21203/rs.3.rs-922547/v1

License: (a) (i) This work is licensed under a Creative Commons Attribution 4.0 International License. Read Full License 


\section{Abstract}

Introduction: Dual users of cigarettes and e-vapor products (EVP) are often considered as a homogenous group even though multiple subgroups may exist. We examined biomarkers of exposure (BOE) and biomarkers of potential harm (BOPH) to differentiate between subgroups of dual users based on PATH Study Wave 1 (2013-2014) data.

Methods: We segmented adult dual users ( $n=970)$ into four subgroups based on the number of days of product used in past 30 days - frequent dual users of both products (FreqDU, $n=169$ ), frequent smokers who vape infrequently (SMVP, $n=678$ ), frequent vapers who smoke infrequently (VPSM, $n=57$ ), and infrequent dual users of both products (InfreqDU, $n=66$ ). Eighteen BOEs (representing exposure to TSNAs, nicotine, heavy metals, PAHs, and volatile organic compounds), and four BOPHs (representing inflammation and oxidative stress) were analyzed within the subgroups, versus exclusive daily cigarette smokers ( $E S M, n=2,442)$ and exclusive daily e-cigarette users (EVP, $n=169)$.

Results: Levels of many BOEs and BOPHs were higher among SMVP relative to FreqDU, VPSM and InfreqDU. Compared to ESM, many BOEs were significantly lower in VPSM (15/18) and InfreqDU (17/18), and some BOEs were higher among SMVP (4/18). InfreqDU showed significantly lower levels of 2/18 BOEs than EVP, and lower levels of 2/4 BOPHs than ESM.

Conclusions: Overall, the levels of BOEs and BOPHs in dual users are associated with frequency of cigarette smoking. Our findings indicate that not all dual users are the same, and tobacco product use frequency should be considered when categorizing dual users.

\section{Implications}

Literature reports indicate that BOEs are higher among dual users relative to exclusive smokers. However, no reports exist regarding biomarker levels across different dual user subgroups. To better understand the heterogeneity among dual users we characterized BOEs and BOPHs among four subgroups of dual users based on PATH Wave 1 data. Our analyses indicate differences in biomarker levels exist among the subgroups. The relative exposure difference appears to be associated with the frequency of cigarette smoking within the subgroups.

Our findings demonstrate that while complete switching from cigarettes is the most desirable outcome for harm reduction, some dual users exhibit substantial reduction in biomarker levels and may be in transition to complete switching suggesting harm reduction potential in a select subgroup of dual users.

\section{Introduction}

In recent years, the tobacco product landscape has changed dramatically with the introduction of e-vapor products (EVP) that deliver nicotine without many of the harmful and potentially harm chemicals (HPHCs) associated with combustion and are therefore potentially less harmful than cigarettes. ${ }^{1,2}$ The onset of EVPs in the marketplace has changed tobacco use behavior as many adult cigarette smokers have either 
switched completely or use EVPs in addition to cigarettes. While dual use of EVPs and combustible cigarettes is not desirable, it may be a transition state for some smokers and/or a means of reducing cigarette consumption for others. ${ }^{3,4}$ Dual use is often an amorphous term, and no well-accepted definition exists. Many studies define dual users differently and vary from: any use of both products in the past 30 days $^{5}$; any current use of both products ${ }^{6}$; weekly use of both products ${ }^{7}$; daily cigarette smoking with every day or some days e-cigarettes use ${ }^{8}$; or daily e-cigarette use with cigarette smoking. ${ }^{9}$

Most published studies examining biomarkers of exposure (BOEs) report results on an average for the entire dual use group, without examining differences within the dual user group. To date, BOEs and biomarkers of potential harm (BOPHs) among various dual user subgroups have not been fully characterized. ${ }^{10} \mathrm{BOEs}$ are closely related to frequency of use, duration of use, and the amount of product use, and the levels often resemble a dose-response relationship. 8,11 Goniewicz et al. have demonstrated that significant differences in exposure exist between self-reported daily and non-daily dual users of cigarettes and e-cigarettes. ${ }^{12}$ Additionally, Sarkar et al. have shown in a controlled clinical setting that dual users of cigarettes and snus, who substantially reduced cigarette smoking, experienced reductions of 36$59 \%$ in several BOEs. ${ }^{13}$ Moreover, others have also shown modest associations with cigarette consumption and biomarker levels of exposure. $8,14-17$ Therefore, it is critical to consider the frequency of tobacco product use when assessing BOEs and BOPHs among dual users.

The goal of this study was to evaluate biomarker levels among dual users of cigarettes and EVPs by segmenting dual users into distinct subgroups based on the self-reported frequency of use as a more refined approach to evaluate BOEs and BOPHs. We compared biomarker levels between dual user subgroups and relative to exclusive daily cigarette smokers, exclusive daily e-cigarette users, and never tobacco users. We analyzed biomarker data from the PATH Wave 1 dataset obtained from a nationally representative sample ${ }^{18}$ that provides real-world evidence among tobacco users and allows for assessment of a comprehensive set of biomarkers.

\section{Methods}

\section{Data Source}

The Population Assessment of Tobacco and Health (PATH) study is a nationally representative, ${ }^{19}$ longitudinal cohort study of tobacco use and health outcomes in the United States conducted by the National Institutes of Health and the Food and Drug Administration (FDA). ${ }^{19}$ Data for the analyses used the merged Wave 1 Adult Questionnaire Restricted-Use Files (RUF) and Biomarker Restricted-Use Files (BRUF), collected from 2013-2014. ${ }^{20,21}$ The BRUF is a stratified probability sample of the larger PATH adult cohort, consisting of 11,522 adults that provided urine samples, allowing for analysis of BOEs. Among these participants, 7,159 also provided a blood sample, allowing for analysis of BOPHs. Additional details on methods for the PATH Study, including design, sampling, interviewing procedures, sample weighting, and biospecimen subsample details are described elsewhere. ${ }^{21}$ 


\section{Selected Sample/Tobacco User Groups/Demographics}

Among the PATH urine biospecimen and blood specimen samples, we selected 5,281 and 3,347 samples respectively based on the definitions of the four major groups and their tobacco use status from adults aged 18 or older for inclusion in the study. For comparison purposes, we defined the groups as follows: 1) "never tobacco users" (urine $n=1,700$; blood $n=986$ ) defined as those who reported never using any tobacco product, even one time; 2) "exclusive daily cigarette smokers" (urine $n=2,442$; blood $n=1,608$ ), defined as those who reported current everyday use of combustible cigarettes and reported no other current tobacco product use; 3) "exclusive daily e-vapor user" (urine $n=169$; blood $n=115$ ), defined as those who reported current everyday use of e-cigarettes and reported no other current tobacco product use; and, 4) "dual cigarette and e-vapor users" (urine $n=970$; blood $n=638$ ) defined as those who reported every day or some day use of both combustible cigarettes and e-cigarettes and reported no other current tobacco product use. For further classification, the "dual cigarette and e-vapor users" group was divided into four subgroups based on the number of days they had used each product in the past 30 days, including 1) "frequent duals" (urine $n=169$; blood $n=117$ ), defined as those who reported use of both products on $\geq 20$ days; 2 ) "smokers who vape" (urine $n=678$; blood $n=439$ ), defined as those who reported cigarette smoking on $\geq 20$ days and vaping on $\leq 19$ days; 3 ) "vapers who smoke" (urine $n=57$; blood $n=37$ ), defined as those who reported cigarette smoking on $\leq 19$ days and vaping on $\geq 20$ days; and 4) "infrequent duals" (urine $n=66$; blood $n=45$ ), defined as those who reported use of both products on $\leq 19$ days. ${ }^{22}$ Study participants with Body Mass Index $(\mathrm{BMI})<15$ or $>50$ were excluded from the sample selection due to potential confounding with biomarker assessments.

We examined the distribution of selected demographic characteristics by tobacco user group including sex, age, race/ethnicity, US census region, educational attainment and BMI. Age categories included 18 to 24 years, 25 to 34 years, 35 to 54 years, and 55 years or older. Race/Ethnicity was categorized as non-Hispanic White, non-Hispanic Other race (Black or African American, American Indian or Alaska Native, Asian, Native Hawaiian or Other Pacific Islander, multi-racial) and Hispanic. Educational attainment was categorized as less than a high school diploma or General Educational Development (GED), high school diploma, some college/associates degree, and bachelor's degree or higher. BMI was derived using self-reported height and weight and further categorized into two groups: 15 to $<25$ and 25 to 50 .

\section{Data Analysis}

In this study, we present results for 18 BOEs to constituents classified by the FDA as HPHCs (Supplemental Table S1) and 4 biomarkers of potential harm - high-sensitivity C-reactive protein (hs-CRP), interleukin-6 (IL6), fibrinogen, and soluble intracellular adhesion molecule (SICAM). Urine creatinine was used to adjust the concentration values of urinary biomarkers to account for creatinine clearance and urine dilution. ${ }^{23}$ All biomarker levels exhibited a skewed distribution, despite creatinine adjustment, therefore biomarker concentrations were natural log-transformed to minimize the effects of skewness and we calculated geometric means of observed biomarker concentrations by tobacco product use category. A linear regression model was used to estimate biomarker levels for each of the tobacco user groups while adjusting for sex, age, race/ethnicity, region, education and BMI. The statistical analysis included 
comparisons between dual user groups, and comparison of dual user groups to exclusive cigarette smokers, exclusive e-cigarette users, and never tobacco users.

Estimates were considered potentially unreliable if the unweighted sample size of a non-proportion estimate or the denominator of a proportion was less than 40 or an estimate was calculated from a sample of which more than $40 \%$ of biomarker values were below the limit of detection (LOD). All analyses were conducted using Statistical Analysis Software (SAS) version 9.4 (SAS Institute, Cary, NC), and all figures were constructed using Microsoft Office Suite. The surveyfreq, surveyreg, and surveymeans procedures were used with restricted-use PATH biomarker data using biomarker sample weights with balanced repeated replication (BRR), and a Fay's adjustment value of 0.3 based on guidance provided in the PATH User Guide to account for the PATH complex survey design. ${ }^{21}$ Confidence intervals for proportions were computed using the Wilson method. ${ }^{24}$ All data analysis and data reporting was completed in accordance with the Inter-university Consortium for Political and Social Research (ICPSR) Virtual Data Enclave (VDE) guidelines within the Institute for Social Research at the University of Michigan and approved by ICPSR for public dissemination.

\section{Results}

\section{Demographic characteristics of the study population by tobacco product use status}

Table 1 presents the characteristics of the study population with urinary biomarker data. Among subgroups of dual users, the proportions of female users were relatively higher among smokers who vape (63.4\%), vapers who smoke (62.1\%), and infrequent duals (65.5\%) than among frequent duals (57.0\%). Among frequent duals, the proportions of white, non-Hispanic (87.7\%) users were higher than any other subgroup of dual users (57.8-78.4\%). Infrequent duals were younger (mean age 38.5 years old) with higher proportions of Hispanics (35.3\%) than any other group (26.3\% vs. $5.6-16.1 \%)$. Vapers who smoke and infrequent duals smoked fewer cigarettes per day (8.4 and 4.8, respectively) than smokers who vaped (15.4). 
Table 1

Demographic characteristics and product use behavior for PATH Wave 1 adult exclusive, dual, and never tobacco users with urinary biomarker data $(\%, 95 \% \mathrm{Cl})^{\text {a }}$

\begin{tabular}{|c|c|c|c|c|c|c|c|}
\hline \multirow[t]{2}{*}{ Characteristics } & \multirow{2}{*}{$\begin{array}{l}\begin{array}{l}\text { Exclusive } \\
\text { daily }\end{array} \\
\text { cigarette } \\
\text { smoker } \\
(n= \\
2,442)\end{array}$} & \multicolumn{4}{|c|}{$\begin{array}{l}\text { Dual cigarette \& } \\
\text { e-vapor user }(n=970)\end{array}$} & \multirow{2}{*}{$\begin{array}{l}\text { Exclusive } \\
\text { daily } \\
\text { e-vapor } \\
\text { user } \\
(n=169)\end{array}$} & \multirow{2}{*}{$\begin{array}{l}\text { Never } \\
\text { tobacco } \\
\text { user } \\
(n= \\
1,700)\end{array}$} \\
\hline & & $\begin{array}{l}\text { Frequent } \\
\text { duals } \\
(n=169, \\
18.0 \%)\end{array}$ & $\begin{array}{l}\text { Smokers } \\
\text { who } \\
\text { vape } \\
(n=678 \text {, } \\
69.2 \%)\end{array}$ & $\begin{array}{l}\text { Vapers } \\
\text { who } \\
\text { smoke } \\
(n=57, \\
5.8 \%)\end{array}$ & $\begin{array}{l}\text { Infrequent } \\
\text { duals } \\
(n=66 \text {, } \\
6.9 \%)\end{array}$ & & \\
\hline
\end{tabular}

Sex

Male

47.6

43.0

$(44.5$

$(33.0$

$50.7)$

53.7)

36.6

(32.1,

41.4)

37.9

(24.0,

34.5 (22.5,

54.1)

48.8)

43.1

(34.9,

37.5

51.6)

(35.0,

40.1)

Female

52.4

57.0

63.4

$(49,3$,

55.5)

(46.3,

67.0)

62.1

(45.9,

(58.6,

76.0)

65.5 (51.2,

56.9

(48.4,

65.1)

62.5

68.0)

77.5)

(59.9,

$46.2 \quad 43.5$

(45.0

(43.3,

(42.0,

49.1)

45.0)

43.1

38.5 (34.7,

43.9

49.8)

42.4)

(41.4

46.4)

65.0)

Age group

(years)

$$
\text { 18-24 }
$$

$7.2(5.8$,

6.7 (3.8,

7.7 (5.9,

15.2

(7.9

27.3)

26.4 (17.2,

38.1)

5.6 (3.0,

16.1

8.8)

11.5

9.9)

220

25-34

19.3

19.0

22.3

(12.7,

21.7)

27.5)

(19.0,

26.1)

22.0
$(11.8$,
$37.5)$

$16.4(9.3$

10.1)

(14.4,

17.9)

44.7

(43.9,

45.6)

\section{$35-54$}

43.6

(40.6,

46.6)

41.6

(31.8,

52.1)

46.5

(42.2,

51.0)

37.5)

27.2)

29.6

(21.8,

38.8)

17.3

(14.9, 20.2)

$55+$

$\begin{array}{ll}29.9 & 32.7 \\ (26.8, & (23.8, \\ 33.2) & 43.0)\end{array}$

23.5

(19.1,

28.6)

$\begin{array}{ll}31.6 & 37.3(25.4, \\ (18.2, & 50.9) \\ 48.9) & \\ 31.1 & 20.0(10.5, \\ (15.3, & 34.6) \\ 53.0) & \end{array}$

36.5

(29.0, 44.7)

35.4

(32.0, 39.0)

\section{Race/ethnicity}

Note: ${ }^{a}$ Estimates are for participants with urinary biomarker weights.

Reported above are weighted percentages and may not add up to 100 due to rounding.

$\wedge$ - recoded because PATH does not ask every day users about their frequency of use in the past 30d.

HS - High School. 


\begin{tabular}{|c|c|c|c|c|c|c|c|}
\hline \multirow[t]{2}{*}{ Characteristics } & \multirow{2}{*}{$\begin{array}{l}\text { Exclusive } \\
\text { daily } \\
\text { cigarette } \\
\text { smoker } \\
(n= \\
2,442)\end{array}$} & \multicolumn{4}{|c|}{$\begin{array}{l}\text { Dual cigarette \& } \\
\text { e-vapor user }(n=970)\end{array}$} & \multirow{2}{*}{$\begin{array}{l}\begin{array}{l}\text { Exclusive } \\
\text { daily }\end{array} \\
\text { e-vapor } \\
\text { user } \\
(n=169)\end{array}$} & \multirow{2}{*}{$\begin{array}{l}\text { Never } \\
\text { tobacco } \\
\text { user } \\
(n= \\
1,700)\end{array}$} \\
\hline & & $\begin{array}{l}\text { Frequent } \\
\text { duals } \\
(n=169, \\
18.0 \%)\end{array}$ & $\begin{array}{l}\text { Smokers } \\
\text { who } \\
\text { vape } \\
(n=678 \text {, } \\
69.2 \%)\end{array}$ & $\begin{array}{l}\text { Vapers } \\
\text { who } \\
\text { smoke } \\
(n=57, \\
5.8 \%)\end{array}$ & $\begin{array}{l}\text { Infrequent } \\
\text { duals } \\
(n=66 \text {, } \\
6.9 \%)\end{array}$ & & \\
\hline $\begin{array}{l}\text { White, Non- } \\
\text { Hispanic }\end{array}$ & $\begin{array}{l}70.5 \\
(66.9 \\
73.9)\end{array}$ & $\begin{array}{l}87.7 \\
(81.2 \\
92.2)\end{array}$ & $\begin{array}{l}78.4 \\
(74.9 \\
81.6)\end{array}$ & $\begin{array}{l}79.2 \\
(66.1 \\
88.2)\end{array}$ & $\begin{array}{l}57.8(44.4, \\
70.2)\end{array}$ & $\begin{array}{l}84.1 \\
(77.5 \\
89.0)\end{array}$ & $\begin{array}{l}56.4 \\
(52.6 \\
60.1)\end{array}$ \\
\hline $\begin{array}{l}\text { Non-Hispanic } \\
\text { Other }\end{array}$ & $\begin{array}{l}19.1 \\
(16.2 \\
22.3)\end{array}$ & $\begin{array}{l}8.2(4.8 \\
13.6)\end{array}$ & $\begin{array}{l}10.9(8.7 \\
13.5)\end{array}$ & $\begin{array}{l}13.4 \\
(6.2 \\
26.7)\end{array}$ & $\begin{array}{l}6.9(2.8 \\
15.7)\end{array}$ & $\begin{array}{l}11.2(7.0 \\
17.5)\end{array}$ & $\begin{array}{l}22.7 \\
(20.1 \\
25.4)\end{array}$ \\
\hline Hispanic & $\begin{array}{l}10.4(8.6 \\
12.5)\end{array}$ & $\begin{array}{l}4.1(1.9 \\
8.4)\end{array}$ & $\begin{array}{l}10.7(8.3 \\
13.7)\end{array}$ & $\begin{array}{l}7.3 \\
(2.9 \\
17.1)\end{array}$ & $\begin{array}{l}35.3(24.1, \\
48.3)\end{array}$ & $\begin{array}{l}4.7(2.4, \\
9.1)\end{array}$ & $\begin{array}{l}21.0 \\
(18.3 \\
23.9)\end{array}$ \\
\hline \multicolumn{8}{|l|}{ Region } \\
\hline Northeast & $\begin{array}{l}19.0 \\
(15.8 \\
22.8)\end{array}$ & $\begin{array}{l}8.1(4.5 \\
13.9)\end{array}$ & $\begin{array}{l}13.4 \\
(10.4 \\
17.2)\end{array}$ & $\begin{array}{l}14.7 \\
(6.8 \\
28.6)\end{array}$ & $\begin{array}{l}11.7(6.0 \\
21.7)\end{array}$ & $\begin{array}{l}9.8(6.2 \\
15.2)\end{array}$ & $\begin{array}{l}18.1 \\
(15.5 \\
21.1)\end{array}$ \\
\hline Midwest & $\begin{array}{l}25.8 \\
(21.8 \\
30.4)\end{array}$ & $\begin{array}{l}29.1 \\
(21.5 \\
38.0)\end{array}$ & $\begin{array}{l}24.1 \\
(20.5 \\
28.1)\end{array}$ & $\begin{array}{l}14.8 \\
(7.2 \\
27.8)\end{array}$ & $\begin{array}{l}19.8(12.0 \\
31.0)\end{array}$ & $\begin{array}{l}29.2 \\
(21.8 \\
37.9)\end{array}$ & $\begin{array}{l}17.9 \\
(15.5 \\
20.5)\end{array}$ \\
\hline South & $\begin{array}{l}40.0 \\
(35.4 \\
44.7)\end{array}$ & $\begin{array}{l}44.9 \\
(35.1 \\
55.1)\end{array}$ & $\begin{array}{l}43.2 \\
(38.0 \\
48.6)\end{array}$ & $\begin{array}{l}52.1 \\
(34.0 \\
69.6)\end{array}$ & $\begin{array}{l}35.3(23.1, \\
49.8)\end{array}$ & $\begin{array}{l}36.2 \\
(27.8 \\
45.6)\end{array}$ & $\begin{array}{l}39.8 \\
(35.6 \\
44.1)\end{array}$ \\
\hline West & $\begin{array}{l}15.2 \\
(12.1 \\
18.9)^{\prime}\end{array}$ & $\begin{array}{l}18.0 \\
(12.1 \\
25.9)\end{array}$ & $\begin{array}{l}19.2 \\
(15.0 \\
24.2)\end{array}$ & $\begin{array}{l}18.5 \\
(8.9 \\
34.5)\end{array}$ & $\begin{array}{l}33.1(20.9, \\
48.2)\end{array}$ & $\begin{array}{l}24.8 \\
(17.0 \\
34.7)\end{array}$ & $\begin{array}{l}24.2 \\
(20.6 \\
28.3)\end{array}$ \\
\hline \multicolumn{8}{|l|}{ Education } \\
\hline $\begin{array}{l}\text { Less than HS } \\
\text { diploma }\end{array}$ & $\begin{array}{l}31.6 \\
(28.9 \\
34.3)\end{array}$ & $\begin{array}{l}23.0 \\
(16.4 \\
31.3)\end{array}$ & $\begin{array}{l}23.4 \\
(20.0 \\
27.1)\end{array}$ & $\begin{array}{l}34.1 \\
(17.1 \\
56.4)\end{array}$ & $\begin{array}{l}18.4(10.0 \\
31.4)\end{array}$ & $\begin{array}{l}13.9(9.2 \\
20.4)\end{array}$ & $\begin{array}{l}16.3 \\
(14.3 \\
18.6)\end{array}$ \\
\hline
\end{tabular}

Note: ${ }^{\text {a }}$ Estimates are for participants with urinary biomarker weights.

Reported above are weighted percentages and may not add up to 100 due to rounding.

$\wedge$ - recoded because PATH does not ask every day users about their frequency of use in the past $30 \mathrm{~d}$.

HS - High School. 


\begin{tabular}{|c|c|c|c|c|c|c|c|}
\hline \multirow[t]{4}{*}{ Characteristics } & \multirow{4}{*}{$\begin{array}{l}\text { Exclusive } \\
\text { daily } \\
\text { cigarette } \\
\text { smoker } \\
(n= \\
2,442)\end{array}$} & \multicolumn{4}{|c|}{$\begin{array}{l}\text { Dual cigarette \& } \\
\text { e-vapor user }(n=970)\end{array}$} & \multirow{4}{*}{$\begin{array}{l}\begin{array}{l}\text { Exclusive } \\
\text { daily }\end{array} \\
\text { e-vapor } \\
\text { user } \\
(n=169)\end{array}$} & \multirow{4}{*}{$\begin{array}{l}\text { Never } \\
\text { tobacco } \\
\text { user } \\
(n= \\
1,700)\end{array}$} \\
\hline & & \multirow{3}{*}{$\begin{array}{l}\text { Frequent } \\
\text { duals } \\
(n=169, \\
18.0 \%)\end{array}$} & \multirow{3}{*}{$\begin{array}{l}\text { Smokers } \\
\text { who } \\
\text { vape } \\
(n=678 \text {, } \\
69.2 \%)\end{array}$} & \multirow{3}{*}{$\begin{array}{l}\text { Vapers } \\
\text { who } \\
\text { smoke } \\
(n=57 \text {, } \\
5.8 \%)\end{array}$} & \multirow{3}{*}{$\begin{array}{l}\text { Infrequent } \\
\text { duals } \\
(n=66 \text {, } \\
6.9 \%)\end{array}$} & & \\
\hline & & & & & & & \\
\hline & & & & & & & \\
\hline HS diploma & $\begin{array}{l}32.5 \\
(29.6 \\
35.5)\end{array}$ & $\begin{array}{l}25.5 \\
(17.8 \\
35.2)\end{array}$ & $\begin{array}{l}24.7 \\
(21.2 \\
28.7)\end{array}$ & $\begin{array}{l}13.7 \\
(6.0 \\
28.3)\end{array}$ & $\begin{array}{l}20.5(11.5 \\
33.8)\end{array}$ & $\begin{array}{l}28.9 \\
(21.5 \\
37.6)\end{array}$ & $\begin{array}{l}25.3 \\
(21.7 \\
29.1)\end{array}$ \\
\hline Some college & $\begin{array}{l}29.5 \\
(26.9 \\
32.4)\end{array}$ & $\begin{array}{l}41.2 \\
(31.1 \\
52.0)\end{array}$ & $\begin{array}{l}37.0 \\
(32.8 \\
41.3)\end{array}$ & $\begin{array}{l}42.5 \\
(25.1 \\
62.0)\end{array}$ & $\begin{array}{l}46.4(33.3, \\
60.0)\end{array}$ & $\begin{array}{l}42.4 \\
(34.3 \\
50.8)\end{array}$ & $\begin{array}{l}27.6 \\
(24.7 \\
30.8)\end{array}$ \\
\hline $\begin{array}{l}\text { Bachelor and } \\
\text { higher }\end{array}$ & $\begin{array}{l}6.4(5.3 \\
7.8)\end{array}$ & $\begin{array}{l}10.3(5.5 \\
18.6)\end{array}$ & $\begin{array}{l}14.9 \\
(11.5 \\
19.2)\end{array}$ & $\begin{array}{l}9.7 \\
(3.8 \\
22.5)\end{array}$ & $\begin{array}{l}14.7(7.6 \\
26.6)\end{array}$ & $\begin{array}{l}14.9 \\
(10.1 \\
21.3)^{\prime}\end{array}$ & $\begin{array}{l}30.8 \\
(27.1 \\
34.7)\end{array}$ \\
\hline \multicolumn{8}{|l|}{$\begin{array}{l}\text { Body Mass } \\
\text { Index }\end{array}$} \\
\hline 15 to $<25$ & $\begin{array}{l}37.0 \\
(33.8 \\
40.2)\end{array}$ & $\begin{array}{l}39.5 \\
(30.8 \\
48.9)\end{array}$ & $\begin{array}{l}36.4 \\
(31.8 \\
41.2)\end{array}$ & $\begin{array}{l}53.7 \\
(41.8 \\
65.6)\end{array}$ & $\begin{array}{l}34.3(23.0, \\
47.7)\end{array}$ & $\begin{array}{l}37.5 \\
(30.1 \\
45.6)\end{array}$ & $\begin{array}{l}33.6 \\
(30.1 \\
37.2)\end{array}$ \\
\hline 25 to 50 & $\begin{array}{l}63.0 \\
(59.8 \\
66.2)\end{array}$ & $\begin{array}{l}60.5 \\
(51.1 \\
69.2)\end{array}$ & $\begin{array}{l}63.6 \\
(58.8 \\
68.2)\end{array}$ & $\begin{array}{l}46.3 \\
(34.4 \\
58.2)\end{array}$ & $\begin{array}{l}65.7(52.3, \\
77.0)\end{array}$ & $\begin{array}{l}62.5 \\
(54.4 \\
69.9)\end{array}$ & $\begin{array}{l}66.4 \\
(62.8 \\
69.9)\end{array}$ \\
\hline $\begin{array}{l}\text { Mean } \\
\text { cigarettes } \\
\text { smoked per } \\
\text { day }\end{array}$ & $\begin{array}{l}15.8 \\
(15.2 \\
16.4)\end{array}$ & $\begin{array}{l}15.0 \\
(13.2 \\
16.8)\end{array}$ & $\begin{array}{l}15.7 \\
(15.0 \\
16.4)\end{array}$ & $\begin{array}{l}8.4 \\
(3.2 \\
13.7)\end{array}$ & $\begin{array}{l}4.8(2.2, \\
7.3)\end{array}$ & - & - \\
\hline $\begin{array}{l}\text { Mean days } \\
\text { smoked in past } \\
\text { 30d }\end{array}$ & $30^{\wedge}$ & $\begin{array}{l}29.2 \\
(28.8 \\
29.6)\end{array}$ & $\begin{array}{l}29.7 \\
(29.6 \\
29.8)\end{array}$ & $\begin{array}{l}6.0 \\
(4.3, \\
7.6)\end{array}$ & $\begin{array}{l}6.5(5.0, \\
8.0)\end{array}$ & - & - \\
\hline $\begin{array}{l}\text { Mean days } \\
\text { vaped in past } \\
30 \mathrm{~d}\end{array}$ & - & $\begin{array}{l}28.8 \\
(28.2 \\
29.4)\end{array}$ & $\begin{array}{l}3.5(3.2, \\
3.9)\end{array}$ & $\begin{array}{l}29.2 \\
(28.6 \\
29.9)\end{array}$ & $\begin{array}{l}3.1(2.0 \\
4.2)\end{array}$ & $30^{\wedge}$ & - \\
\hline \multicolumn{8}{|c|}{ Note: ${ }^{a}$ Estimates are for participants with urinary biomarker weights. } \\
\hline \multicolumn{8}{|c|}{ Reported above are weighted percentages and may not add up to 100 due to rounding. } \\
\hline \multicolumn{8}{|c|}{ ^ - recoded because PATH does not ask every day users about their frequency of use in the past $30 \mathrm{~d}}$. \\
\hline HS - High Schoo & & & & & & & \\
\hline
\end{tabular}

\section{Analysis of BOEs by tobacco product user group}




\section{Comparisons of BOEs within dual user subgroups}

Supplemental Table S2 presents biomarker concentrations across tobacco product user groups for 18 BOEs to HPHCs listed in Supplemental Table S1. Among dual user subgroups, vapers who smoke had significantly $(p<0.01)$ lower levels of 15 of the 18 BOEs (NNAL, NNN, 2-FLU, 3-FLU, 1-PYR, AAMA, CEMA, CYMA, 2-HPMA, 3-HPMA, HPMM, IPM3, MADA, MHB3, and PHGA) than smokers who vape. Infrequent duals showed significantly $(p<0.05)$ lower levels of 5 of the 18 BOEs (TNE-7, NNAL, NNN, cadmium, and PHGA) than vapers who smoke. Overall biomarker levels were different among subgroups of dual users (Fig. 1): highest among smokers who vape and lowest among Infrequent duals (Fig. 2).

\section{Comparisons of BOEs between dual user subgroups and exclusive cigarette smokers}

The majority of biomarker levels (15 out of 18 ) for frequent duals were similar to exclusive daily cigarette smokers, except for CYMA, HPMM, and MHB3 which were significantly lower $(p<0.05$; Fig. 1$)$. Overall, smokers who vape had significantly higher levels of NNAL, 1-PYR, and MHB3, and significantly lower levels of NNN $(p<0.05)$ than exclusive cigarette smokers (Supplemental Table S2). In general, there were significantly lower levels of most biomarkers among vapers who smoke and infrequent duals than exclusive daily cigarette smokers. Infrequent duals had significantly $(p<0.0001)$ lower levels of 17 of the 18 BOEs (TNE-7, NNAL, NNN, cadmium, 2-FLU, 3-FLU, 1-PYR, AAMA, CEMA, CYMA, 2-HPMA, 3-HPMA, HPMM, IPM3, MADA, MHB3, and PHGA) compared to exclusive daily cigarette smokers. Similarly, vapers who smoke had significantly $(p<0.01)$ lower levels of 15 of the 18 BOEs (NNAL, NNN, 2-FLU, 3-FLU, 1-PYR, AAMA, CEMA, CYMA, 2-HPMA, 3-HPMA, HPMM, IPM3, MADA, MHB3, and PHGA) than exclusive smokers.

\section{Comparisons of BOEs between dual user subgroups and exclusive e-vapor users}

While most biomarkers among dual user subgroups were higher than exclusive e-vapor users, lower biomarker levels were observed among those with lower frequency of cigarette smoking (Fig. 2; Supplemental Figure S1). Infrequent duals showed significantly $(p<0.05)$ lower levels of 2 of the 18 BOEs (TNE-7 and cadmium) than exclusive daily e-vapor users.

\section{Analysis of BOPHs by tobacco product user group status Comparisons of BOPHs between dual user subgroups}

Supplemental Table S3 presents the overall geometric mean concentrations of BOPHs across tobacco product user groups. Among dual user subgroups, vapers who smoke had significantly $(p=0.0321)$ lower levels IL- 6 than smokers who vape, and smokers who vape had higher levels of hs-CRP and IL-6 ( $p=0.05$ for both) than frequent duals (Supplemental Table S3).

\section{Comparisons of BOPHs between dual user subgroups and exclusive cigarette smokers}


Overall, there were no significant differences in biomarker levels between frequent duals or smokers who vape and exclusive cigarette smokers. The levels of BOPHs were lower among infrequent duals (hs-CRP: 1.28 ( $p=0.1817)$; IL-6: $1.61(p=0.5665)$; sICAM: $227.81(p<0.0001)$; Fibrinogen: $304.32(p<0.05))$ as well among vapers who smoke (hs-CRP: 1.34 ( $p=0.4307)$; IL-6: $1.26(p<0.05)$; IICAM: 259.68 ( $p=0.3539)$; Fibrinogen: $312.11(p=0.2825)$ ) compared to exclusive daily cigarette smokers (Fig. 3 ).

\section{Comparisons of BOPHs between dual user subgroups and exclusive e-vapor users}

Frequent duals had significantly higher levels of hs-CRP $(p=0.0042)$, $\operatorname{sICAM}(p<0.0001)$, and Fibrinogen ( $p$ $=0.009)$ than exclusive e-vapor users. Smokers who vape had significantly higher levels of hs-CRP $(p<$ $0.0001)$, IL-6 $(p=0.0009)$, sICAM $(p<0.0001)$, and Fibrinogen $(p=0.0015)$, whereas vapers who smoke and infrequent duals did not have significantly different levels of BOPHs compared to exclusive daily e-vapor users (Supplemental Figure S2).

\section{Discussion}

This study assessed the BOEs and BOPHs among dual users of cigarettes and e-cigarettes by segmenting the dual users into subgroups based on self-reported product use frequency to better assess relative exposure to toxicants and carcinogens within dual user subgroups. Vapers who smoke and infrequent dual users, overall, had lower levels of biomarkers compared to exclusive smokers. On the other hand, smokers who vape, on average, had similar levels of most biomarkers compared to exclusive smokers. The overall levels of exposure were found to be associated with cigarette consumption (i.e., number of days used in the past 30 days) and not associated with e-cigarette use. We analyzed data from the PATH study as it provides the most comprehensive set of biomarkers collected from a large, real-world population-based sample representative of tobacco users in the non-institutionalized U.S. adult population.

The current study provides insights by disentangling dual users into various subgroups rather than the more commonly published reports that consider dual users as a single homogenous group. Notable differences in demographic composition and tobacco use behaviors among the dual user subgroups highlight the heterogeneity in the dual tobacco use category. Every dual user is uniquely defined by the product use behavior, therefore, assessing dual users as a single group does not provide an accurate representation of the exposure levels within the category. For example, a recent study found higher levels of TNE-2, NNAL, 1-HOP, HPMA, and MHB3 among dual users of cigarettes and e-cigarettes compared to exclusive cigarette users. ${ }^{8}$ That study only provided an assessment of dual users who were every day smokers in the PATH Wave 1 Study, excluding "some days" cigarette smokers who make up a significant number of all dual users. Some of these "some days" dual users report frequent use of cigarette smoking ( $\geq 20$ days) and have high mean levels of biomarkers of exposure even though they consider themselves as "some days" users. Goniewicz et al. reported that dual users of cigarettes and e-cigarettes were also exposed to higher levels of nicotine, two heavy metals (lead and cadmium), five PAHs and thirteen VOCs, than current exclusive cigarette smokers. However, the analysis of dual users segmented by daily and nondaily use of both products provided a more refined assessment of BOEs - daily smokers had higher levels 
of toxicants than non-daily smokers. ${ }^{12}$ Recently, Stokes et al. reported no difference in the biomarker concentration of inflammatory (hSCRP, IL-6, fibrinogen, S-ICAM) or oxidative stress (urinary 8-isoprostane) between exclusive smokers and dual users of cigarettes and e-cigarettes. ${ }^{25}$ The dual user group was defined as a single group without differentiating the frequency of use of both products. Majeed et al. reported clusters of tobacco user population based on the exposure levels; however, our approach provides a unique understanding of exposure among different dual user subgroups based on their product use behavior. $^{26}$

Our study corroborates the findings regarding BOEs reported by Smith et al. ${ }^{27}$, indicating that a clear pattern is emerging. As suggested by Borland et al. ${ }^{28}$ product use frequency is an important indicator for identifying subsets of dual users. We demonstrate that among the four subgroups, those dual users that vape frequently and infrequent dual users, smoked fewer cigarettes and therefore, are lower on the continuum of exposure relative to frequent smokers that vape infrequently and frequent dual users.

Our analysis complements these findings by gaining additional insights from the BOPH levels. The differences in BOPHs within the dual subgroups aligns with the differences in BOEs. All the BOPHs investigated in the infrequent dual user subgroup were comparable to the exclusive e-vapor user and the never tobacco user groups. These observations suggest that dual users exhibiting lower exposure may start moving down the path to lowering the adverse health effects from cigarette smoke. A dose-response relationship exists between cigarette smoking and the mortality from many of the smoking diseases, ${ }^{29}$ and such a relationship is even acknowledged by the U.S. Surgeon General in the 2004 report on the Health Consequences of Smoking. ${ }^{30}$ Moreover, in a meta-analysis of published literature, Chang et al. ${ }^{31}$ report that substantial reduction in cigarette consumption may lower some smoking-related disease risks. While quitting all tobacco products is the most desirable outcome for harm reduction, for those adult smokers unable or unwilling to quit, increased use of e-vapor and ultimately switching to exclusive e-vapor use may provide some benefits. Sustained and large reductions in exposure, like that observed among exclusive evapor users compared to exclusive smokers, should reduce the risks of many of the smoking related diseases.

Our analyses should be considered in the context of some potential limitations. Given the cross-sectional nature of our analysis, conclusions cannot be made regarding transitions between the groups; however, the insights about relative exposure are noteworthy. Self-reported product usage can be viewed as yet another limitation as this is subject to various sources of error (e.g., recall bias, social desirability). Nevertheless, self-reported characterization of tobacco product use is widely used by most researchers and is reportedly considered a reasonable approach. ${ }^{32-34}$ Furthermore, the BOE levels provide confirmation of their classification into various subgroups. The relatively small size $(n=45)$, among some dual user subgroups and for some biomarkers, may limit generalizability to the population. Moreover, the e-vapor usage behavior during the period of data collection (2013-2014) may not reflect the current use behavior as the evapor products have evolved over time from the earlier generation products to the currently popular podbased products. This limitation can be offset in the future by updating these analyses as more recent biomarker data become available. Lastly, the PATH study only measured cigarette smoke-related BOEs and 
did not include biomarkers related to e-vapor constituents primarily due to the ubiquitous nature of the major constituents, propylene glycol and glycerin, and unknown long-term effects and associated biomarkers. ${ }^{35}$

In conclusion, we have demonstrated that dual users of e-vapor products and cigarettes are not a single homogenous group. At least four distinct subgroups were identified based on the frequency of tobacco product use and a continuum of exposure exists within the dual user subgroups. Overall, the levels of BOE and BOPHs in dual users are associated with frequency of cigarette smoking. In order to experience potential harm reduction, dual users must switch completely.

\section{Declarations}

\section{Ethics approval and consent to participate}

The Population Assessment of Tobacco and Health (PATH) Study is a national longitudinal study of tobacco use and how it affects the health of people in the United States. The PATH Study, which started in 2013 , is a collaboration between the National Institutes of Health $(\mathrm{NIH})$ and the Food and Drug Administration (FDA). The study was conducted by Westat and approved by the Westat Institutional Review Board. Westat's IRB operates in accordance with the regulations set forth by the Office for Human Research Protections within the U.S. Department of Health and Human Services under 45 CFR Part 46, the Common Rule. Our analysis is based on data accessed through Inter-University Consortium for Political and Social Research (ICPSR) at University of Michigan.

\section{Consent for publication}

All adult participants (age 18 and older) provided informed consent, and adult participants who agreed to give biospecimens provided separate informed consent.

\section{Availability of data and materials}

The biomarker data was accessed through ICPSR PATH Study Wave 1 Biomarker Restricted Use Files. The datasets analyzed during the current study can be requested from ICPSR. The specific codes utilized to analyze the dataset will be available from the corresponding author on reasonable request.

\section{Competing interests}

The authors are/were employees of Altria Client Services LLC at the time the work was completed.

\section{Funding}

N/A

\section{Authors' contributions}


$\mathrm{PL}, \mathrm{RN}, \mathrm{JE}$ and MS were involved in conceptualization of the analysis, BN was involved in data acquisition; $\mathrm{PL}$ and $\mathrm{LW}$ conducted the data analysis; $\mathrm{PL}, \mathrm{RN}, \mathrm{LW}, \mathrm{JE}, \mathrm{EB}$, and RB were involved in the interpretation of the results and developing the outline of the manuscript; $P L$ and MS were primarily involved in writing the manuscript, with input and review from RN, LW, JE, EB and RB.

\section{Acknowledgements}

The authors acknowledge the staff at ICPSR for providing access to the data files.

\section{References}

1. Royal College of Physicians. Nicotine without Smoke-Tobacco Harm Reduction. London: RCP; 2016.

2. National Academies of Sciences Engineering \& Medicine. Public Health Consequences of E-Cigarettes. Washington, D.C.2018.

3. Brose LS, Hitchman SC, Brown J, West R, McNeill A. Is the use of electronic cigarettes while smoking associated with smoking cessation attempts, cessation and reduced cigarette consumption? A survey with a 1-year follow-up. Addiction. 2015;110:1160-8.

4. Pasquereau A, Guignard R, Andler R, Nguyen-Thanh V. Electronic cigarettes, quit attempts and smoking cessation: a 6-month follow-up. Addiction. 2017;112(9):1620-8.

5. Christensen T, Welsh E, Faseru B. Profile of e-cigarette use and its relationship with cigarette quit attempts and abstinence in Kansas adults. Prev Med. 2014;69:90-4.

6. Simonavicius E, McNeill A, Arnott D, Brose LS. What factors are associated with current smokers using or stopping e-cigarette use? Drug alcohol dependence. 2017;173:139-43.

7. Levy DT, Borland R, Villanti AC, et al. The Application of a Decision-Theoretic Model to Estimate the Public Health Impact of Vaporized Nicotine Product Initiation in the United States. Nicotine Tob Res. 2016.

8. Rostron BL, Corey CG, Chang JT, van Bemmel DM, Miller ME, Chang CM. Associations of Cigarettes Smoked Per Day with Biomarkers of Exposure Among US Adult Cigarette Smokers in the Population Assessment of Tobacco and Health (PATH) Study Wave 1 (2013-2014). Cancer epidemiology, biomarkers \& prevention: a publication of the American Association for Cancer Research, cosponsored by the American Society of Preventive Oncology. 2019.

9. Biener L, Hargraves JL. A longitudinal study of electronic cigarette use among a population-based sample of adult smokers: association with smoking cessation and motivation to quit. Nicotine Tob Res. 2015;17:127-33.

10. Chang CM, Edwards SH, Arab A, Del Valle-Pinero AY, Yang L, Hatsukami DK. Biomarkers of Tobacco Exposure: Summary of an FDA-Sponsored Public Workshop. Cancer epidemiology, biomarkers \& prevention: a publication of the American Association for Cancer Research. cosponsored by the American Society of Preventive Oncology. 2017;26(3):291-302.

11. Hatsukami DK, Benowitz NL, Rennard SI, Oncken C, Hecht SS. Biomarkers to assess the utility of potential reduced exposure tobacco products. Nicotine Tob Res. 2006;8:600-22. 
12. Goniewicz ML, Smith DM, Edwards KC, et al. Comparison of Nicotine and Toxicant Exposure in Users of Electronic Cigarettes and Combustible Cigarettes. JAMA network open. 2018;1(8):e185937.

13. Sarkar M, Liu J, Koval T, et al. Evaluation of biomarkers of exposure in adult cigarette smokers using Marlboro snus. Nicotine Tob Res. 2010;12:105-16.

14. Krautter GR, Borgerding MF. Comparison of consumption patterns, biomarkers of exposure, and subjective effects in cigarette smokers who switched to dissolvable tobacco (Camel Orbs), dual use, or tobacco abstinence. Nicotine Tob Res. 2014;16(10):1336-47.

15. Krautter GR, Chen PX, Borgerding MF. Consumption patterns and biomarkers of exposure in cigarette smokers switched to Snus, various dissolvable tobacco products, Dual use, or tobacco abstinence. Regulatory toxicology pharmacology: RTP. 2015;71(2):186-97.

16. Hatsukami DK, Stepanov I, Severson H, et al. Evidence supporting product standards for carcinogens in smokeless tobacco products. Cancer Prev Res (Phila). 2015;8:20-6.

17. Rostron BL, Corey CG, Chang JT, van Bemmel DM, Miller ME, Chang CM. Changes in Cigarettes per Day and Biomarkers of Exposure Among US Adult Smokers in the Population Assessment of Tobacco and Health Study Waves 1 and 2 (2013-2015). Nicotine Tob Res. 2020.

18. Hyland A, Ambrose BK, Conway KP, et al. Design and methods of the Population Assessment of Tobacco and Health (PATH) Study. Tobacco Control. 2016.

19. Hyland A, Ambrose BK, Conway KP, et al. Design and methods of the Population Assessment of Tobacco and Health (PATH) Study. Tob Control. 2017;26(4):371-8.

20. U.S. Department of Health and Human Services. National Institutes of Health. Center for Tobacco Products. Population Assessment of Tobacco and Health (PATH) Study [United States] Public-Use Files. In: Inter-university Consortium for Political and Social Research (ICPSR); 2017.

21. U.S. Department of Health and Human Services. National Institutes of Health. Center for Tobacco Products. Population Assessment of Tobacco and Health (PATH) Study [United States] Restricted-Use Files. In: Inter-university Consortium for Political and Social Research [distributor]; 2020.

22. Kasza KA, Edwards KC, Tang Z, et al. Correlates of tobacco product cessation among youth and adults in the USA: findings from the PATH Study Waves 1-3 (2013-2016). Tobacco control. 2020;29(Suppl 3):s203-15.

23. Boeniger MF, Lowry LK, Rosenberg J. Interpretation of urine results used to assess chemical exposure with emphasis on creatinine adjustments: a review. Am Ind Hyg Assoc J. 1993;54(10):615-27.

24. Wilson EB. Probable Inference, the Law of Succession, and Statistical Inference. Journal of the American Statistical Association. 1927;22(158):209-12.

25. Stokes AC, Xie W, Wilson AE, et al. Association of Cigarette and Electronic Cigarette Use Patterns With Levels of Inflammatory and Oxidative Stress Biomarkers Among US Adults: Population Assessment of Tobacco and Health Study. Circulation. 2021.

26. Majeed B, Linder D, Eissenberg T, Tarasenko Y, Smith D, Ashley D. Cluster analysis of urinary tobacco biomarkers among U.S. adults: Population Assessment of Tobacco and Health (PATH) biomarker study (2013-2014). Prev Med. 2020:106218. 
27. Smith DM, Christensen C, van Bemmel D, et al. Exposure to Nicotine and Toxicants Among Dual Users of Tobacco Cigarettes and E-Cigarettes: Population Assessment of Tobacco and Health (PATH) Study, 2013-2014. Nicotine Tob Res. 2021;23(5):790-7.

28. Borland R, Murray K, Gravely S, et al. A new classification system for describing concurrent use of nicotine vaping products alongside cigarettes (so-called 'dual use'): findings from the ITC-4 Country Smoking and Vaping wave 1 Survey. Addiction. 2019.

29. Inoue-Choi M, Christensen $\mathrm{CH}$, Rostron BL, et al. Dose-Response Association of Low-Intensity and Nondaily Smoking With Mortality in the United States. JAMA network open. 2020;3(6):e206436.

30. Office of the Surgeon G. Office on S, Health. Reports of the Surgeon General. In: The Health Consequences of Smoking: A Report of the Surgeon General. Atlanta (GA): Centers for Disease Control and Prevention (US); 2004.

31. Chang JT, Anic GM, Rostron BL, Tanwar M, Chang CM. Cigarette Smoking Reduction and Health Risks: A Systematic Review and Meta-analysis. Nicotine Tob Res. 2021;23(4):635-42.

32. Jarvis MJ, Primatesta P, Erens B, Feyerabend C, Bryant A. Measuring nicotine intake in population surveys: comparability of saliva cotinine and plasma cotinine estimates. Nicotine Tob Res. 2003;5(3):349-55.

33. Yeager DS, Krosnick JA. The validity of self-reported nicotine product use in the 2001-2008 National Health and Nutrition Examination Survey. Med Care. 2010;48(12):1128-32.

34. Wray JM, Gass JC, Miller El, Wilkins DG, Rollins DE, Tiffany ST. A comparative evaluation of self-report and biological measures of cigarette use in nondaily smokers. Psychological assessment. 2016;28(9):1043-50.

35. Landmesser A, Scherer M, Pluym N, et al. Biomarkers of Exposure Specific to E-vapor Products Based on Stable-Isotope Labeled Ingredients. Nicotine Tob Res. 2019;21(3):314-22.

\section{Tables}

Table 1. Demographic characteristics and product use behavior for PATH Wave 1 adult exclusive, dual, and never tobacco users with urinary biomarker data $(\%, 95 \% \mathrm{Cl})^{\text {a }}$ 


\begin{tabular}{|c|c|c|c|c|c|c|c|}
\hline \multirow[t]{2}{*}{ Characteristics } & \multirow{2}{*}{$\begin{array}{l}\text { Exclusive } \\
\text { daily } \\
\text { cigarette } \\
\text { smoker } \\
(n=2,442)\end{array}$} & \multicolumn{4}{|c|}{$\begin{array}{l}\text { Dual cigarette \& } \\
\text { e-vapor user }(n=970)\end{array}$} & \multirow{2}{*}{$\begin{array}{l}\text { Exclusive } \\
\text { daily } \\
\text { e-vapor } \\
\text { user } \\
(n=169)\end{array}$} & \multirow{2}{*}{$\begin{array}{l}\text { Never } \\
\text { tobacco } \\
\text { user } \\
(n=1,700)\end{array}$} \\
\hline & & $\begin{array}{c}\text { Frequent } \\
\text { duals } \\
(n=169, \\
18.0 \%)\end{array}$ & $\begin{array}{l}\text { Smokers } \\
\text { who } \\
\text { vape } \\
(n=678 \text {, } \\
69.2 \%)\end{array}$ & $\begin{array}{l}\text { Vapers } \\
\text { who } \\
\text { smoke } \\
(n=57, \\
5.8 \%)\end{array}$ & $\begin{array}{l}\text { Infrequent } \\
\text { duals } \\
\text { (n=66, } \\
6.9 \%)\end{array}$ & & \\
\hline \multicolumn{8}{|l|}{ Sex } \\
\hline Male & $\begin{array}{l}47.6 \\
(44.5 \\
50.7)\end{array}$ & $\begin{array}{l}43.0 \\
(33.0 \\
53.7)\end{array}$ & $\begin{array}{l}36.6 \\
(32.1, \\
41.4)^{\prime}\end{array}$ & $\begin{array}{l}37.9 \\
(24.0 \\
54.1)\end{array}$ & $\begin{array}{l}34.5 \\
(22.5 \\
48.8)\end{array}$ & $\begin{array}{l}43.1 \\
(34.9 \\
51.6)\end{array}$ & $\begin{array}{l}37.5 \\
(35.0 \\
40.1)\end{array}$ \\
\hline Female & $\begin{array}{l}52.4 \\
(49,3 \\
55.5)\end{array}$ & $\begin{array}{l}57.0 \\
(46.3 \\
67.0)\end{array}$ & $\begin{array}{l}63.4 \\
(58.6 \\
68.0)\end{array}$ & $\begin{array}{l}62.1 \\
(45.9 \\
76.0)\end{array}$ & $\begin{array}{l}65.5 \\
(51.2 \\
77.5)\end{array}$ & $\begin{array}{l}56.9 \\
(48.4 \\
65.1)\end{array}$ & $\begin{array}{l}62.5 \\
(59.9 \\
65.0)\end{array}$ \\
\hline Age (mean) & $\begin{array}{l}46.0 \\
(45.0 \\
47.0)\end{array}$ & $\begin{array}{l}46.2 \\
(43.3 \\
49.1)\end{array}$ & $\begin{array}{l}43.5 \\
(42.0 \\
45.0)\end{array}$ & $\begin{array}{l}43.1 \\
(36.5 \\
49.8)\end{array}$ & $\begin{array}{l}38.5 \\
(34.7 \\
42.4)\end{array}$ & $\begin{array}{l}43.9 \\
(41.4 \\
46.4)\end{array}$ & $\begin{array}{l}44.7 \\
(43.9 \\
45.6)\end{array}$ \\
\hline \multicolumn{8}{|l|}{$\begin{array}{l}\text { Age group } \\
\text { (years) }\end{array}$} \\
\hline $18-24$ & $\begin{array}{l}7.2(5.8, \\
8.8)\end{array}$ & $\begin{array}{l}6.7(3.8 \\
11.5)\end{array}$ & $\begin{array}{l}7.7(5.9, \\
9.9)\end{array}$ & $\begin{array}{l}15.2 \\
(7.9 \\
27.3)\end{array}$ & $\begin{array}{l}26.4 \\
(17.2 \\
38.1)\end{array}$ & $\begin{array}{l}5.6(3.0 \\
10.1)\end{array}$ & $\begin{array}{l}16.1 \\
(14.4 \\
17.9)\end{array}$ \\
\hline $25-34$ & $\begin{array}{l}19.3 \\
(17.1 \\
21.7)^{\prime}\end{array}$ & $\begin{array}{l}19.0 \\
(12.7 \\
27.5)^{\prime}\end{array}$ & $\begin{array}{l}22.3 \\
(19.0 \\
26.1)\end{array}$ & $\begin{array}{l}22.0 \\
(11.8 \\
37.5)\end{array}$ & $\begin{array}{l}16.4(9.3 \\
27.2)\end{array}$ & $\begin{array}{l}29.6 \\
(21.8 \\
38.8)\end{array}$ & $\begin{array}{l}17.3 \\
(14.9 \\
20.2)\end{array}$ \\
\hline $35-54$ & $\begin{array}{l}43.6 \\
(40.6 \\
46.6)\end{array}$ & $\begin{array}{l}41.6 \\
(31.8 \\
52.1)\end{array}$ & $\begin{array}{l}46.5 \\
(42.2 \\
51.0)\end{array}$ & $\begin{array}{l}31.6 \\
(18.2 \\
48.9)\end{array}$ & $\begin{array}{l}37.3 \\
(25.4 \\
50.9)\end{array}$ & $\begin{array}{l}36.5 \\
(29.0 \\
44.7)\end{array}$ & $\begin{array}{l}35.4 \\
(32.0 \\
39.0)\end{array}$ \\
\hline $55+$ & $\begin{array}{l}29.9 \\
(26.8 \\
33.2)\end{array}$ & $\begin{array}{l}32.7 \\
(23.8 \\
43.0)\end{array}$ & $\begin{array}{l}23.5 \\
(19.1 \\
28.6)\end{array}$ & $\begin{array}{l}31.1 \\
(15.3 \\
53.0)\end{array}$ & $\begin{array}{l}20.0 \\
(10.5 \\
34.6)\end{array}$ & $\begin{array}{l}28.3 \\
(21.6 \\
36.2)\end{array}$ & $\begin{array}{l}31.1 \\
(27.9 \\
34.5)\end{array}$ \\
\hline \multicolumn{8}{|l|}{ Race/ethnicity } \\
\hline $\begin{array}{l}\text { White, Non- } \\
\text { Hispanic }\end{array}$ & $\begin{array}{l}70.5 \\
(66.9 \\
73.9)\end{array}$ & $\begin{array}{l}87.7 \\
(81.2 \\
92.2)\end{array}$ & $\begin{array}{l}78.4 \\
(74.9 \\
81.6)\end{array}$ & $\begin{array}{l}79.2 \\
(66.1 \\
88.2)\end{array}$ & $\begin{array}{l}57.8 \\
(44.4 \\
70.2)\end{array}$ & $\begin{array}{l}84.1 \\
(77.5 \\
89.0)\end{array}$ & $\begin{array}{l}56.4 \\
(52.6 \\
60.1)\end{array}$ \\
\hline $\begin{array}{l}\text { Non-Hispanic } \\
\text { Other }\end{array}$ & $\begin{array}{l}19.1 \\
(16.2 \\
22.3)\end{array}$ & $\begin{array}{l}8.2(4.8 \\
13.6)\end{array}$ & $\begin{array}{l}10.9 \\
(8.7 \\
13.5)\end{array}$ & $\begin{array}{l}13.4 \\
(6.2 \\
26.7)\end{array}$ & $\begin{array}{l}6.9(2.8 \\
15.7)\end{array}$ & $\begin{array}{l}11.2(7.0 \\
17.5)\end{array}$ & $\begin{array}{l}22.7 \\
(20.1 \\
25.4)^{\prime}\end{array}$ \\
\hline Hispanic & $\begin{array}{l}10.4(8.6 \\
12.5)\end{array}$ & $\begin{array}{l}4.1(1.9 \\
8.4)\end{array}$ & $\begin{array}{l}10.7 \\
(8.3 \\
13.7)\end{array}$ & $\begin{array}{l}7.3 \\
(2.9 \\
17.1)\end{array}$ & $\begin{array}{l}35.3 \\
(24.1, \\
48.3)\end{array}$ & $\begin{array}{l}4.7(2.4, \\
9.1)\end{array}$ & $\begin{array}{l}21.0 \\
(18.3 \\
23.9)\end{array}$ \\
\hline \multicolumn{8}{|l|}{ Region } \\
\hline Northeast & $\begin{array}{l}19.0 \\
(15.8\end{array}$ & $\begin{array}{l}8.1(4.5 \\
13.9)\end{array}$ & $\begin{array}{l}13.4 \\
(10.4\end{array}$ & $\begin{array}{l}14.7 \\
(6.8\end{array}$ & $\begin{array}{l}11.7(6.0 \\
21.7)\end{array}$ & $\begin{array}{l}9.8(6.2 \\
15.2)\end{array}$ & $\begin{array}{l}18.1 \\
(15.5\end{array}$ \\
\hline
\end{tabular}




\begin{tabular}{|c|c|c|c|c|c|c|c|}
\hline & 22.8) & & 17.2) & 28.6) & & & 21.1) \\
\hline Midwest & $\begin{array}{l}25.8 \\
(21.8 \\
30.4)\end{array}$ & $\begin{array}{l}29.1 \\
(21.5 \\
38.0)\end{array}$ & $\begin{array}{l}24.1 \\
(20.5 \\
28.1)\end{array}$ & $\begin{array}{l}14.8 \\
(7.2, \\
27.8)\end{array}$ & $\begin{array}{l}19.8 \\
(12.0 \\
31.0)\end{array}$ & $\begin{array}{l}29.2 \\
(21.8 \\
37.9)\end{array}$ & $\begin{array}{l}17.9 \\
(15.5, \\
20.5)\end{array}$ \\
\hline South & $\begin{array}{l}40.0 \\
(35.4 \\
44.7)\end{array}$ & $\begin{array}{l}44.9 \\
(35.1 \\
55.1)\end{array}$ & $\begin{array}{l}43.2 \\
(38.0 \\
48.6)\end{array}$ & $\begin{array}{l}52.1 \\
(34.0 \\
69.6)\end{array}$ & $\begin{array}{l}35.3 \\
(23.1 \\
49.8)\end{array}$ & $\begin{array}{l}36.2 \\
(27.8 \\
45.6)\end{array}$ & $\begin{array}{l}39.8 \\
(35.6, \\
44.1)\end{array}$ \\
\hline West & $\begin{array}{l}15.2 \\
(12.1 \\
18.9)\end{array}$ & $\begin{array}{l}18.0 \\
(12.1, \\
25.9)^{\prime}\end{array}$ & $\begin{array}{l}19.2 \\
(15.0 \\
24.2)\end{array}$ & $\begin{array}{l}18.5 \\
(8.9 \\
34.5)\end{array}$ & $\begin{array}{l}33.1 \\
(20.9 \\
48.2)\end{array}$ & $\begin{array}{l}24.8 \\
(17.0 \\
34.7)\end{array}$ & $\begin{array}{l}24.2 \\
(20.6, \\
28.3)\end{array}$ \\
\hline \multicolumn{8}{|l|}{ Education } \\
\hline $\begin{array}{l}\text { Less than HS } \\
\text { diploma }\end{array}$ & $\begin{array}{l}31.6 \\
(28.9 \\
34.3)\end{array}$ & $\begin{array}{l}23.0 \\
(16.4 \\
31.3)\end{array}$ & $\begin{array}{l}23.4 \\
(20.0 \\
27.1)\end{array}$ & $\begin{array}{l}34.1 \\
(17.1 \\
56.4)\end{array}$ & $\begin{array}{l}18.4 \\
(10.0 \\
31.4)\end{array}$ & $\begin{array}{l}13.9(9.2 \\
20.4)\end{array}$ & $\begin{array}{l}16.3 \\
(14.3, \\
18.6)\end{array}$ \\
\hline HS diploma & $\begin{array}{l}32.5 \\
(29.6 \\
35.5)\end{array}$ & $\begin{array}{l}25.5 \\
(17.8 \\
35.2)\end{array}$ & $\begin{array}{l}24.7 \\
(21.2 \\
28.7)\end{array}$ & $\begin{array}{l}13.7 \\
(6.0 \\
28.3)\end{array}$ & $\begin{array}{l}20.5 \\
(11.5 \\
33.8)\end{array}$ & $\begin{array}{l}28.9 \\
(21.5 \\
37.6)\end{array}$ & $\begin{array}{l}25.3 \\
(21.7 \\
29.1)^{\prime}\end{array}$ \\
\hline Some college & $\begin{array}{l}29.5 \\
(26.9 \\
32.4)\end{array}$ & $\begin{array}{l}41.2 \\
(31.1 \\
52.0)\end{array}$ & $\begin{array}{l}37.0 \\
(32.8 \\
41.3)\end{array}$ & $\begin{array}{l}42.5 \\
(25.1 \\
62.0)\end{array}$ & $\begin{array}{l}46.4 \\
(33.3 \\
60.0)\end{array}$ & $\begin{array}{l}42.4 \\
(34.3 \\
50.8)\end{array}$ & $\begin{array}{l}27.6 \\
(24.7 \\
30.8)^{\prime}\end{array}$ \\
\hline $\begin{array}{l}\text { Bachelor and } \\
\text { higher }\end{array}$ & $\begin{array}{l}6.4(5.3, \\
7.8)\end{array}$ & $\begin{array}{l}10.3 \\
(5.5, \\
18.6)\end{array}$ & $\begin{array}{l}14.9 \\
(11.5, \\
19.2)\end{array}$ & $\begin{array}{l}9.7 \\
(3.8 \\
22.5)\end{array}$ & $\begin{array}{l}14.7(7.6 \\
26.6)\end{array}$ & $\begin{array}{l}14.9 \\
(10.1 \\
21.3)^{\prime}\end{array}$ & $\begin{array}{l}30.8 \\
(27.1, \\
34.7)^{\prime}\end{array}$ \\
\hline \multicolumn{8}{|l|}{$\begin{array}{l}\text { Body Mass } \\
\text { Index }\end{array}$} \\
\hline 15 to $<25$ & $\begin{array}{l}37.0 \\
(33.8 \\
40.2)\end{array}$ & $\begin{array}{l}39.5 \\
(30.8 \\
48.9)\end{array}$ & $\begin{array}{l}36.4 \\
(31.8 \\
41.2)\end{array}$ & $\begin{array}{l}53.7 \\
(41.8 \\
65.6)\end{array}$ & $\begin{array}{l}34.3 \\
(23.0 \\
47.7)\end{array}$ & $\begin{array}{l}37.5 \\
(30.1 \\
45.6)\end{array}$ & $\begin{array}{l}33.6 \\
(30.1, \\
37.2)^{\prime}\end{array}$ \\
\hline 25 to 50 & $\begin{array}{l}63.0 \\
(59.8 \\
66.2)\end{array}$ & $\begin{array}{l}60.5 \\
(51.1 \\
69.2)^{\prime}\end{array}$ & $\begin{array}{l}63.6 \\
(58.8 \\
68.2)\end{array}$ & $\begin{array}{l}46.3 \\
(34.4 \\
58.2)\end{array}$ & $\begin{array}{l}65.7 \\
(52.3 \\
77.0)\end{array}$ & $\begin{array}{l}62.5 \\
(54.4 \\
69.9)\end{array}$ & $\begin{array}{l}66.4 \\
(62.8, \\
69.9)\end{array}$ \\
\hline $\begin{array}{l}\text { Mean } \\
\text { cigarettes } \\
\text { smoked per } \\
\text { day }\end{array}$ & $\begin{array}{l}15.8 \\
(15.2 \\
16.4)\end{array}$ & $\begin{array}{l}15.0 \\
(13.2 \\
16.8)\end{array}$ & $\begin{array}{l}15.7 \\
(15.0 \\
16.4)\end{array}$ & $\begin{array}{l}8.4 \\
(3.2 \\
13.7)\end{array}$ & $\begin{array}{l}4.8(2.2, \\
7.3)\end{array}$ & - & - \\
\hline $\begin{array}{l}\text { Mean days } \\
\text { smoked in } \\
\text { past 30d }\end{array}$ & $30^{\wedge}$ & $\begin{array}{l}29.2 \\
(28.8 \\
29.6)\end{array}$ & $\begin{array}{l}29.7 \\
(29.6 \\
29.8)\end{array}$ & $\begin{array}{l}6.0 \\
(4.3, \\
7.6)\end{array}$ & $\begin{array}{l}6.5(5.0 \\
8.0)\end{array}$ & - & - \\
\hline $\begin{array}{l}\text { Mean days } \\
\text { vaped in past } \\
30 \mathrm{~d}\end{array}$ & - & $\begin{array}{l}28.8 \\
(28.2 \\
29.4)\end{array}$ & $\begin{array}{l}3.5(3.2, \\
3.9)\end{array}$ & $\begin{array}{l}29.2 \\
(28.6 \\
29.9)\end{array}$ & $\begin{array}{l}3.1(2.0 \\
4.2)\end{array}$ & $30^{\wedge}$ & - \\
\hline
\end{tabular}

Note: ${ }^{a}$ Estimates are for participants with urinary biomarker weights.

Reported above are weighted percentages and may not add up to 100 due to rounding. 
$\wedge$ - recoded because PATH does not ask every day users about their frequency of use in the past $30 \mathrm{~d}$.

HS - High School.

\section{Figures}

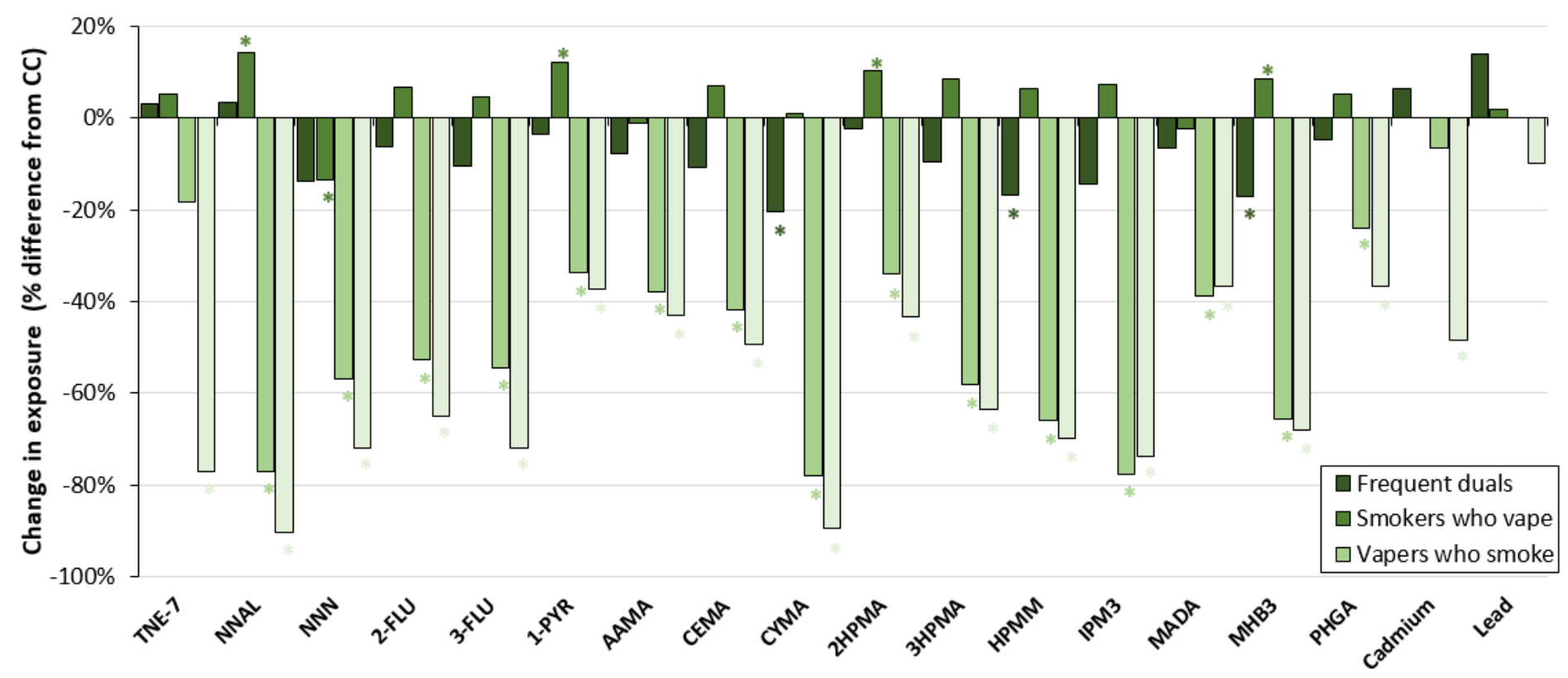

Figure 1

Biomarkers of exposure among dual user subgroups relative to exclusive cigarette smokers, Population Assessment of Tobacco and Health Study Wave 1, 2013-2014 Abbreviations: TNE-7: Total Nicotine Equivalents -7; NNAL: 4-(methylnitrosamino)-1-(3-pyridyl)-1-butanol; NNN: N'-Nitrosonornicotine; 2-FLU: 2hydroxyfluorene; 3-FLU: 3-hydroxyfluorene; 1-PYR: 1-hydroxypyrene; AAMA: N-Acetyl-S-(2-carbamoylethyl)-Lcysteine; CEMA: N-Acetyl-S-(2-carboxyethyl)-L-cysteine; CYMA: N-Acetyl-S-(2-cyanoethyl)-L-cysteine; 2HPMA: N-Acetyl-S-(2-hydroxypropyl)-L-cysteine; 3HPMA: N-Acetyl-S-(3-hydroxypropyl)-L-cysteine; HPMM: N-Acetyl-S-(3-hydroxypropyl-1-methyl)-L-cysteine; IPM3: N-Acetyl-S-(4-hydroxy-2-methyl-2-buten-1-yl)-Lcysteine; MADA - Mandelic acid; MHB3: N-Acetyl-S-(4-hydroxy-2-buten-1-yl)-L-cysteine; PHGA Phenylglyoxylic acid 
NNAL

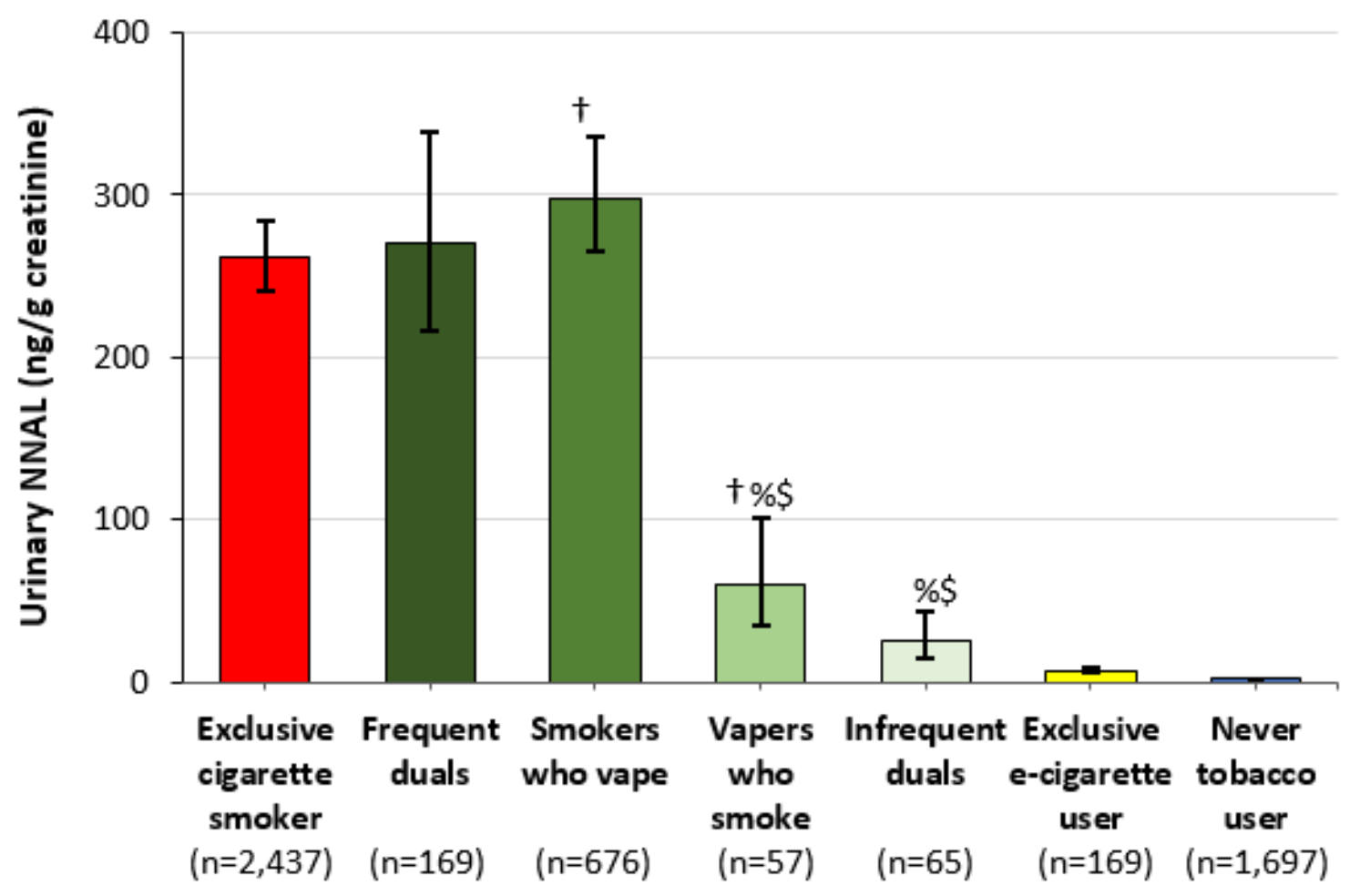

Figure 2

Exposure to NNK among exclusive cigarette smokers, dual user subgroups, exclusive e-cigarette users, and never tobacco users, Population Assessment of Tobacco and Health Study Wave 1, 2013-2014 Note : † - vs. exclusive daily cigarette smokers; * - Smokers who vape vs. Frequent dual; \% - Vapers who smoke vs. Smokers who vape; \& - Infrequent duals vs. Vapers who smoke; \$ - vs. exclusive daily e-vapor user. 


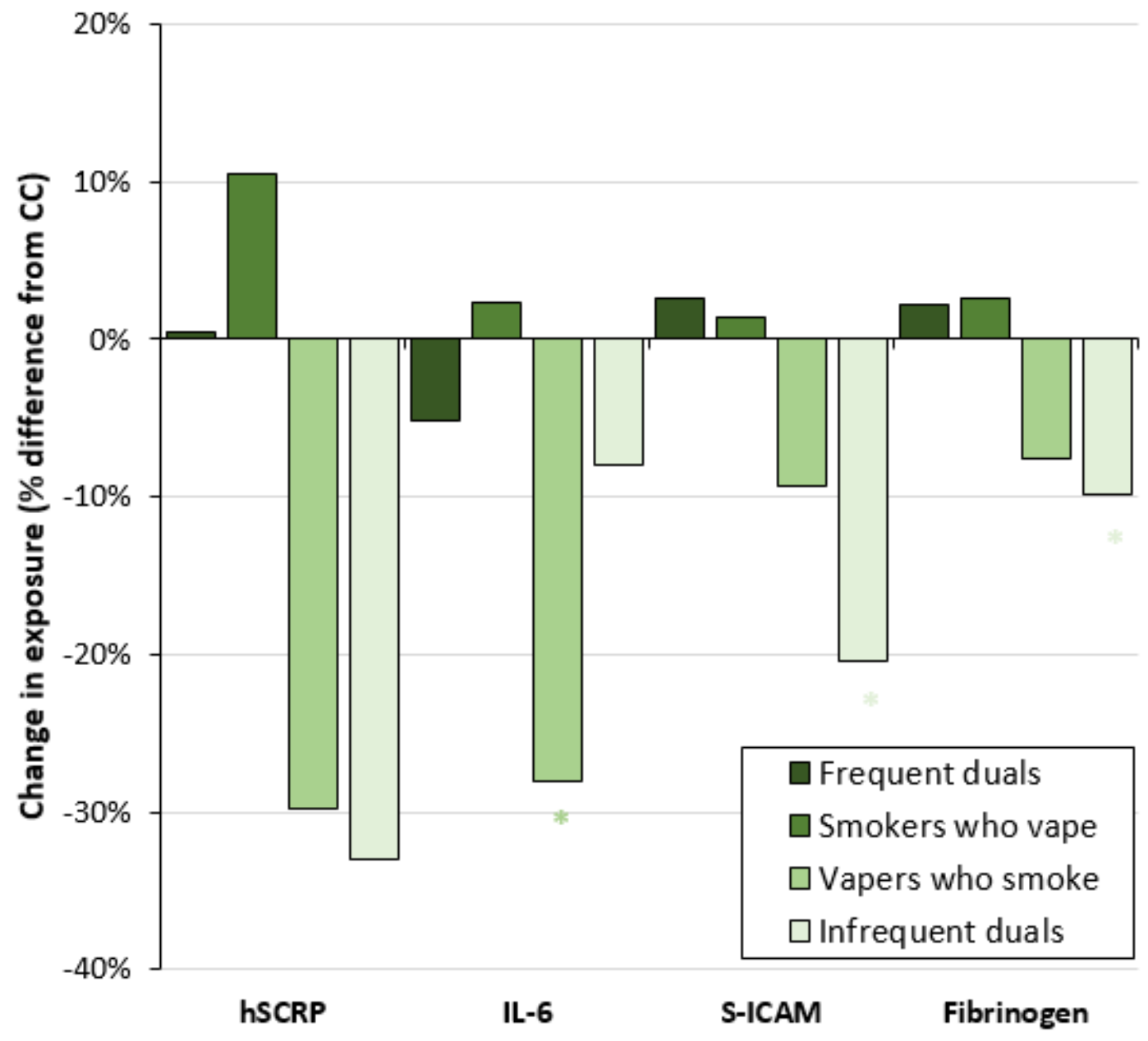

Figure 3

Biomarkers of potential harm among dual user subgroups relative to exclusive cigarette smokers, Population Assessment of Tobacco and Health Study Wave 1, 2013-2014

\section{Supplementary Files}

This is a list of supplementary files associated with this preprint. Click to download.

- SUPPLEMENTALTABLESANDFIGURES.docx 